\title{
The Application of Team-Assisted Individualization (TAI) Type with Multimedia in Improving Social Science Learning about Types of Jobs in Grade III Students of SD Negeri 1 Tamanwinangun in Academic Year 2018/2019
}

\author{
Kartika Tunggal Dewi ${ }^{1}$, Ngatman $^{2}$, Joharman $^{3}$ \\ 1,2.3Universtas Sebelas Maret \\ kartika11@gmail.com
}

\section{Article History}

accepted $\mathrm{xx} / \mathrm{xx} / \mathrm{xxx}$

\begin{abstract}
This study aimed to describe the steps for implementing Team-Assisted Individualization (TAI) type of learning model and improve social science learning about the types of jobs in grade III students. This research is a collaborative Classroom Action Research (CAR) carried out in three cycles. Each cycle consists of two meetings. The data used were quantitative data and qualitative data. The technique of collecting data used tests, observations, interviews, and documentation. The validity of the data used triangulation techniques, source triangulation, and content validity. Data analysis included data reduction, data presentation, and conclusion drawing. The results showed that the application of the type of Team-Assisted Individualization (TAI) learning model could improve social science learning about the types of jobs in grade III students which was known through the increase in the average percentage of students completeness by $60.71 \%$ in the first cycle, $76.78 \%$ in cycle II, and $89.28 \%$ in cycle III.
\end{abstract}

Keywords: TAl model, social science, types of jobs

\begin{abstract}
Abstrak
Penelitian ini bertujuan untuk menggambarkan langkah-langkah untuk menerapkan model pembelajaran Team-Assisted Individualization (TAI) dan meningkatkan pembelajaran ilmu sosial tentang jenis pekerjaan pada siswa kelas III. Penelitian ini merupakan Penelitian Tindakan Kelas kolaboratif (PTK) yang dilaksanakan dalam tiga siklus. Setiap siklus terdiri dari dua pertemuan. Data yang digunakan adalah data kuantitatif dan data kualitatif. Teknik pengumpulan data menggunakan tes, observasi, wawancara, dan dokumentasi. Validitas data menggunakan teknik triangulasi, triangulasi sumber, dan validitas isi. Analisis data meliputi reduksi data, penyajian data, dan penarikan kesimpulan. Hasil penelitian menunjukkan bahwa penerapan model pembelajaran Team-Assisted Individualization (TAI) dapat meningkatkan pembelajaran IPA tentang jenis pekerjaan pada siswa kelas III yang diketahui melalui peningkatan persentase rata-rata ketuntasan siswa sebesar $60,71 \%$ pada siklus pertama, $76,78 \%$ pada siklus II, dan $89,28 \%$ pada siklus III.
\end{abstract}

Kata kunci: model TAl, ilmu sosial, jenis pekerjaan 


\section{PENDAHULUAN}

Menurut Winataputra (2003: 132) bahwa Pendidikan IPS adalah suatu penyederhanaan ilmu-ilmu sosial, ideologi begara dan disiplin ilmu lainnya serta masalah-masalah sosial terkait yang di organisasikan dan di sajikan secara ilmiah untuk tujuan pendidikan pada tingkat dasar dan menengah.

Tujuan IPS menurut Trianto (2007:128) adalah untuk mengembangkan potensi peserta didik agar peka terhadap masalah sosial yang terjadi di masyarakat, memiliki sikap mental positif terhadap perbaikan segala ketimpangan yang terjadi sehari-hari baik yang menimpa dirinya sendiri maupun yang menimpa masyarakat.

Berdasarkan observasi dan wawancara yang dilakukan pada 1 Oktober 2018 dengan wali kelas III, didapatkan data bahwa kondisi pembelajaran IPS di SD Negeri 1 Tamanwinangun ditinjau dari tujuan IPS siswa belum memiliki sikap mental yang positif dan kemampuan bekerjasama masih kurang terbukti ketika proses pembelajaran berlangsung siswa masih sibuk berbicara dengan temannya dan tidak memperhatikan penjelasan guru, ketika melakukan diskusi beberapa anak masih diam. Siswa juga masih merasa takut untuk melakukan presentasi didepan kelas dan mereka belum belajar dengan kondisi yang menyenangkan. Siswa merasa pembelajaran IPS tidak menarik dan membosankan karena banyak hafalannya apalagi tidak adanya media yang mengkonkretkan materi tersebut menggunakan simbol-simbol visual.

Dilihat dari proses pembelajaran IPS yang belum menggunakan model pembelajaran inovatif dan menyenangkan, ketika guru menjelaskan materi pembelajaran guru belum menyesuaikan media yang digunakan dengan materi yang dipelajari pada hari itu. Supaya pembelajaran IPS tidak membosankan, sebaiknya guru menggunakan model pembelajaran yang inovatif.

Inovasi dalam pembelajaran tersebut bertujuan untuk meningkatkan kualitas dan keaktifan siswa dalam pembelajaran. Salah satu model yang dapat diterapkan ialah model pembelajaran kooperatif tipe Team Assisted Individualization (TAI).

Menurut Daryanto dan Rahardjo (2012: 246-247), Team Assisted Individualization (TAl) adalah model pembelajaran kooperatif yang setiap siswa secara individual belajar materi pembelajaran yang sudah dipersiapkan guru kemudian hasil belajar individu dibawa ke kelompok untuk didiskusikan bersama anggota kelompok lainnya dan semua anggota kelompok bertanggung jawab atas keseluruan jawaban sebagai tanggung jawab bersama. Team Assisted Individualization (TAI) dikembangkan oleh Salvin. Tipe ini mengkombinasikan keunggulan pembelajaran kooperatif dan pembelajaran individual.

Corey (Sagala, 2011: 61) mengemukakan bahwa pembelajaran adalah suatu proses lingkungan seseorang secara disengaja dikelola untuk memungkinkan anak turut serta dalam tingkah laku tertentu dalam kondisi khusus atau menghasilkan respons terhadap situasi tertentu..

Berdasarkan uraian di atas, peneliti tertarik untuk melaksanakan penelitian tindakan kelas yang berjudul "Penerapan Tipe Team Assisted Individualization (TAl) dengan Multimedia dalam Peningkatan Pembelajaran IPS tentang Jenis Pekerjaan pada Siswa Kelas III SD Negeri 1 Tamanwinangun Tahun Ajaran 2018/2019".

Diharapkan dengan penelitian ini dapat meningkatkan pembelajaran IPS tentang Jenis Pekerjaan pada siswa kelas III SD Negeri 1 Tamanwinangun.

Berdasarkan uraian di atas, maka dapat dirumuskan masalah yang muncul yaitu: (1) bagaimakah langkah-langkah penerapan model Team Assisted Individualization (TAI) dengan multimedia dalam peningkatan pembelajaran IPS tentang Jenis Pekerjaan di kelas III SD Negeri 1 Tamanwinangun, (2) apakah penerapan Team Assisted Individualization (TAl) dengan multimedia dapat meningkatkan pembelajaran IPS tentang Jenis Pekerjaan di kelas III SD Negeri 1 Tamanwinangun, dan (3) Kendala dan solusi apa saja yang ditemukan pada penerapan model Team Assisted 
Individualization (TAI) dengan multimedia dalam peningkatan pembelajaran IPS tentang Jenis Pekerjaan di kelas III SD Negeri 1 Tamanwinangun.

\section{METODE}

Metode penelitian yang digunakan dalam penelitian ini berupa penelitian tindakan kelas kolaboratif. Peneliti berkolaborasi dengan guru kelas III SDN 1 Tamanwinangun tahun ajaran $2018 / 2019$. Pada penelitian ini, peneliti hanya melibatkan guru sebagai tim pokok untuk melaksanakan tindakan. Peneliti hanya bertindak sebagai perencana dan observer. Penelitian tindakan kelas ini menggunakan model penelitian yang dikembangkan Arikunto, Suhardjono \& Supardi (2014: 16) yang setiap siklusnya terdiri dari tahap perencanaan, pelaksanaan, pengamatan, dan refleksi.

Subjek dalam penelitian ini adalah siswa kelas III SD N 1 Tamanwinangun yang berjumlah 28 siswa. Jenis data penelitian ini adalah data kualitatif berupa hasil observasi dan wawancara penerapan model pembelajaran tipe Team Assisted Individualization (TAl) dengan multimedia dan data kuantitatif berupa hasil tes siswa dalam mata pelajaran IPS.

Teknik pengumpulan data menggunakan tes, obsservasi, wawancara dan dokumentasi. Validitas data menggunakan triangulasi teknik, triangulasi sumber dan validitas isi. Analisis data meliputi reduksi data, penyajian data, dan penarikan kesimpulan. Indikator kinerja penelitian ini adalah peningkatan pembelajaran IPS dengan target yang ditetapkan $85 \%$ dan ketuntasan minimal siswa dengan target $85 \%$.

Penelitian ini dilaksanakan selama tiga siklus dengan menerapkan tujuh langkah model pembelajaran tipe Team Assisted Individualization (TAI) dengan multimedia yaitu: (1) penyampaian materi, (2) pemberian tugas individu, (3) pembentukan tim, (4) kelompok belajar, (5) kelompok pengajaran, (6) tes fakta, dan (7) skor dan rekognisi.

Hasil observasi terhadap pelaksanaan pembelajaran IPS dengan menerapkan model pembelajaran tipe Team Assisted Individualization (TAI) dengan multimedia mengalami peningkatan pada setiap siklusnya yaitu:

Tabel 1. Persentase Hasil Pengamatan Penerapan model pembelajaran tipe Team Assisted Individualization (TAI) dengan multimedia

\begin{tabular}{|c|c|c|c|}
\hline \multirow{2}{*}{$\begin{array}{l}\text { Sumber } \\
\text { data }\end{array}$} & \multicolumn{3}{|l|}{ Siklus } \\
\hline & I & II & III \\
\hline Guru & 75,83 & 84,02 & 90,67 \\
\hline Siswa & 78,83 & 84,62 & 91,36 \\
\hline
\end{tabular}

Hasil pengamatan terhadap guru pada siklus I ke siklus II meningkat sebesar $8,19 \%$ dari $75,83 \%$, menjadi $84,02 \%$, dan pada siklus II ke siklus III meningkat sebesar $6,65 \%$ dari $84,02 \%$ menjadi $90,67 \%$. Persentase hasil pengamatan pada siswa juga mengalami peningkatan pada siklus I ke siklus II sebesar $5,79 \%$ yaitu dari $78,83 \%$ menjadi $84,62 \%$ dan pada siklus II ke siklus III meningkat sebesar $6,74 \%$ dari $84,62 \%$ menjadi $91,36 \%$. 
Tabel 2. Analisis Hasil Belajar Siswa Siklus I, II, dan III

\begin{tabular}{llll}
\hline & $\begin{array}{l}\text { Siklus } \\
\text { I }\end{array}$ & $\begin{array}{l}\text { Siklus } \\
\text { II }\end{array}$ & $\begin{array}{l}\text { Siklus } \\
\text { III }\end{array}$ \\
\hline Tuntas & 60,71 & 76,78 & 89,28 \\
$\begin{array}{l}\text { Belum } \\
\text { Tuntas }\end{array}$ & 39,28 & 23,21 & 10,71 \\
\hline
\end{tabular}

Berdasarkan data di atas, dapat diketahui bahwa persentase ketuntasan hasil belajar siswa pada siklus I ke siklus II meningkat sebesar $16,07 \%$ dari $60,71 \%$ menjadi $76,78 \%$ dan dari siklus II ke siklus III meningkat sebesar $12,50 \%$ dari $76,78 \%$ menjadi $89,28 \%$.

Berdasarkan tabel 1 tersebut dapat disimpulkan bahwa penerapan model pembelajaran tipe Team Assisted Individualization (TAI) dengan multimedia sudah dilaksanakan dengan baik dan sudah melampaui target indikator kinerja penelitian yang ditetapkan yaitu sebesar $85 \%$. Berdasarkan tabel 2 dapat disimpulkan bahwa ketuntasan minimal siswa sudah meampaui target indikator kinerja penelitian yang ditetapkan sebesar $85 \%$ dan terdapat kenaikan persentase di setiap siklusnya.

\section{SIMPULAN}

Berdasarkan hasil penelitian dan pembahasan yang telah diuraikan, maka dapat disimpulkan bahwa: (1) penerapan model pembelajaran tipe Team Assisted Individualization (TAI) dengan multimedia dilakukan dengan tujuh langkah yaitu: (a) penyampaian materi, (b) pemberian tugas individu, (c) pembentukan tim, (d) kelompok belajar, (e) kelompok pengajaran, (f) tes fakta, dan (g) skor dan rekognisi; 2) Penerapan model pembelajaran tipe Team Assisted Individualization (TAl) dengan multimedia dapat meningkatkan pembelajaran IPS tentang Jenis Pekerjaan pada siswa kelas III SD N 1 Tamanwinangun yang dilihat dari kenaikan persentase ketuntasan siswa yaitu pada siklus I sebesar $60,71 \%$, pada siklus II meningkat menjadi $76,78 \%$, dan pada siklus III meningkat menjadi $89,28 \%$; 3) Kendala yang dihadapi pada saat melaksanakan model pembelajaran tipe Team Assisted Individualization (TAI) dengan multimedia adalah (a) guru kurang menguasai kelas, (b) masih ada beberapa siswa yang gaduh saat pembelajaran, (c) masih ada siswa yang belum aktif, (d) kegiatan evaluasi dan penguatan kurang menyeluruh. Solusi yang yang dapat digunakan adalah (a) sharing pada guru dan siswa untuk lebih mempersiapkan pembelajaran, (b) guru lebih mengkondisikan siswa supaya tidak gaduh, (c) memotivasi dan mendorong siswa supaya lebih aktif, (d)mendorong siswa ntuk jujur dalam mengerjakan soal evaluasi.

\section{DAFTAR PUSTAKA}

Arikunto, S., Suhardjono, \& Supardi. (2014). Penelitian Tindakan Kelas. Jakarta: Bumi Aksara.

Daryanto \& Rahardjo, M. (2012). Model Pembelajaran Inovatif. Yogyakarta: Gava Media.

Sagala, S. (2011). Konsep dan Makna Pembelajaran. Bandung: Alfabeta.

Trianto. (2007). Model Pembelajaran Terpadu dalam Teori dan Praktek. Jakarta: Prestasi Pustaka.

Winataputra, dkk. (2003). Strategi Belajar Mengajar. Jakarta: Pusat Penerbitan Universitas Terbuka. 